\title{
Evaluation of Placement and Protection Programs of Indonesian Migrant Worker
}

\author{
Abdul Wahab Samad ${ }^{1}$, Billy Tunas ${ }^{2}$, Muchlis R. Ludin ${ }^{3}$ \\ ${ }^{1}$ Doktoral Program, Human Resource Management, Jakarta State University \\ ${ }^{2}$ Lecturer, Jakarta State University, Indonesia \\ ${ }^{3}$ Lecturer, Jakarta State University, Indonesia
}

\begin{abstract}
The purpose of this study is to evaluate the placement and protection programs of Indonesian migrant worker that they run by the Ministry of Manpower and The National Agency of Placement and Protection of Indonesian Migrant Worker. This research is done by observation, interview and documentation with Discrepancy Evaluation Model method. The method is to evaluate design, installation, process and the Implementation of the Placement and Protection programs of Indonesian Migrant Worker against the Employment Placement Private Company to provide Indonesian migrant workers services licensed by the Ministry of Manpower and placement permits from The National Agency for Placement and Protection of Indonesian Migran Worker, the role of local government on one-stop integrated service, the role of labor attaches in Indonesian embassy from the Ministry of Manpower and supervision of The National Agency for Placement and Protection of Indonesian Migrant Worker. The conclusion of this study indicates that there is a gap in discrepancy at $16.01 \%$ from the target to be achieved.
\end{abstract}

Keywords: program, placement and protection of Indonesian migrant worker, Discrepancy Evaluation Model, design, installation, process, implementation, licensing, local government, labor attaches, and supervision.

\section{Introduction}

The fact of the placement of illegal Indonesian migrant workers has never stopped. The placement of Indonesian migrant workers in abroad will always occur until the availability of employment in entire country is sufficient for the labor force.

Utilization of human resources as accordingly viewed from the point of existence, according to Crhistos Pantzalis (2009), “Human Capital comprises the phsical and intelectual skills and capabilities acquared through education and training that anable an individual to perform tasks efectivily and to be productive". But according to Dave Ulrich (2009), "In the last 50 years, HR professionals have moved from industrial relations where they negotiate the terms and conditions of work to personnel specialists who have expertise in HR practices like recruiting, compensation, training, and organizational development to business partners who deliver value to business success".

Dave Ulrich (2013) findings for presents global on performance management ie; Establishing clear performance standards; Establishing a clear process of performance assesment, with welldefined performance metrics; Providing rich feedback on strengths and needs for improvement and development; Rewarding and recognizing good performance; to utilize the human resource. In other word, Dave Ulrich (2013), to recommended; Equity, Transparency, and Meaninfulness in this case. For more specific, Dave Ulrich (2013) argue, teaching employee and line managers skill in providing and receiving feedback; would be adapting performance standard.

Talking about the performance standards, can not be separated from the activities undertaken. Catherine Truss (2012), stated the coverage of the comparison of Human Resources activities. Different from Peter Drucker (1961), the scope of human resource activity is a personnel administration that is considered largely to a collection of incidental of technical activities without much internal cohesion. As personnel administration personnel have the task of managing their workers and jobs, it is partly the work of the employees, part of the organization's 
household chores, some work from social workers, and some firefighting work or faced by unions who face difficulties to complete given the required task

Peter Drucker expressed his doubt that they should be united in one department so that they could work on their own behalf like the relationship between the people in the farm for labor organization to express performance standard.

Meanwhile, Catherine Truss (2012) states: It is interesting to compare the scope of Drucker's Human Resource activities in the 1960s with the latest framework and influence on Human Resource activities in the Charter Institute of Personnel and Development (CIPD) charterred, UK. The map of Professional Human Resource comprise details for ten areas where CIPD is believed to be owned by Human Resource Manager by demonstrating their expertise, ie (1) Organization design; (2) Organization development; (3) Resourcing and talent planning; (4) Learning and talent development; (5) Performance and reward; (6) Employee engagement; (7) Employee relations; (8) Sevice delivery and information; (9) Strategy insights and solutions; (10) Leading and managing the Human Resource function.

Leading and managing Human Resource functions including leading and managing organizational activities through strategies that are suitable for Human Resource functions and objectives is very indispensable.

Associated with the strategy in developing human resources, David Wilkins and Greg Carolin (2013) suggests some typical strategy that can be used such as (1) A Strategy Driven by a User or Customer Class; (2) A Strategy Driven by Market Type of Category; (3) A Strategy Driven by Technology of Know - How; (4) A Strategy Driven by Sales or Marketing Method; (5) A Strategy Driven by Distribution Method; (6) A Strategy Driven by Natural Resources; (7) A Strategy Driven by Size or Growth.

In implementing a strategy, performance management is the deciding factor. According to Bradlay W. Hall (2008), “Today's approach for improving workforce performance is failing. There are three reasons: (1) No one is accountable for year-over-year human capital performance, (2) Results require a system, not world-class programs. (3). Today's HR model is misaligned to deliver business results".
To overcome for the sollution of performance, the approach that can be taken, "Outperforming competitor organizations in areas of corporate core competencies requires performance excellence in three critical roles: (1) Effective executive teams, (2) Leaders who deliver results, (3) Key position excellence".

Associated with performance sollution that became the center of competence, Dean and Linda Ackerman Anderson (2010) stating that:

Succesful transformation and breakthrough result require competent attention to three critical areas: (1) content, (2) people, and (3) process. Content refers to what about the organization needs to change, such as strategy, stucture, systems, process, technology, products, services, work practices, and so on. Content refers to the tangible aspects of the organization under going change, which are quite observable and reside in the external world we can all see. People refers to the human dynamics of change, including behaviors, skills, emotions, mindset, culture, motivation, communications, engagement, relationship, and politics. People includes the less tangible, "soft" dynamics of the inner thoughts and feelings of the human being who are redesigning, implementing, supporting, or being impacted by the change. Process refers to how the content and people changes will be planned for, designed, and implemented. In other words, process denotes the decisions and actions that will produce both the content and people outcomes.

For the change, Driver of Change Model, explain what drives change, especially transformational change. This model explains four key determinants that are close to traditional leaders and the three relatively new determinants of change that are focus for many people.

Dean Anderson (2010) further states that:The external drivers - environment, marketplace, business, and organization - clearly more familiar to leaders, while the more internal and personal ones - culture, behavior, and mindset - are now to most, yet equally essential. Many of the current struggle with transformation area result of leaders not attending to the people components or not attending to them ways that make real impact.

According to Jon Ingham (2008), in approaching the fundamental strength of culture, which is required to move according to need, is influenced by 3 (three) principles which become the guidance in human capital management that is; 
This strengths-based approach is woven into everything we do, with three fundamental principles guiding our approach to human capital management; (1) Focus on talent for the job at all levels, by building tools and processes that identify, reward and retain high performing employees, (2) Help individual employees know and focus on their strengths and, where necessary, manage their limitations, (3) The development of exceptional managers and leaders who can identify and develop talent and build employee engagement.

Associated with the organizational performance of the human capital of a country, Robert Galavan, Jhon Murray, and Costas Markides (2008) argued that from the demand side, citizens and politicians are far more demanding than was formerly with regard to performance. They expect 'performance' where formarly they placed and more emphasis on process and presence: to be there to act in the rulebased manner was, often enough, acceptable. Now, they demand that capacity to decide, design, and implement be immediately available and result delivered. They expect their results to match the best international standards. They expect the apparatus of government to be responsive, and to deliver performance in a manner that is fast, flexible, efficient, and innovative - but also well considered, cost effective, compliant with demanding governance and accountability requirements, and true to values of an independent public service. If there deep-rooted conficts beween some of these imperatives, it is seen as the job of public manager to get on with it and resolve such a conflicts as arise - without compromising the desiderate.

Mark P. Salsbury (2013), argues that in building and preparing societies with complex cultures, where human capital is to put into an activity or program, there are at least 3 (three) reasons why development and planning are needed:1) Largescale human capital projects require multiple actions and as a result, many hands make lighter work. Simply state, the preparation work needing completion can be done faster with more people. 2) Having capable people who can provide insights, feedback, and help mold the key aspects of a project is a good quality control approach. Increasing per-launch involvement of a limited number of people who can perform the early preparatory work will enhance the quality of the outcome. 3) Every human capital project needs to have champions ready to carry enthusiasm to the project. Waiting until after the announcement and start of a project to enlist and engage champions will create a gap in the process, and require senior management to sell more than necessary. While it's senior management's responsibility to communicate and sell the initiative continuously, having additional champions can have a more transmissible effect in generating organizational motivation and commitment.

Salsbury (2013) further said, In particular, there is one specific point to make regarding the relationship between the organizational structure and the processes and policies spoke. As we've seen in the previous defenition of the roles and responsibilities of people within the organization. This most logically achieved through job description, but they aren't enough. Organization are living, breathing organisms, where defined roles and responsibilities often overlap between individuals who perform different functions. In order for roles and responsibilities to be carried out as planned, it's important for key processes to be established, and to set policies outlining the rules of the organizatioan.

The combination of these structures, processes, and policies in primarily what should drive the operational behavior of the organization as it seeks to accomplish its mission. Nonetheles, in the majority of instances when I've been observer of organization structure changes, the changes in structure were announced to the organization before anyone considered how the decision making processes and policies would be impacted.

\section{Objectives}

This study aims to obtain of design information compiled on the placement and protection programs for Indonesian migrant worker, to obtain information and mapping on the installation of the placement and protection programs for Indonesian migrant worker, to obtain information on the implementation of the proses implementation in placement and protection programs for Indonesian migrant worker and to know the information about the implementation of the placement and protection programs for Indonesian migrant worker. The goals is to answer the question on how the design, installation, process and implementation of the programs could increase the protection of the right of Indonesian migrant workers and their families.

\section{Review Literatur}




\section{A. Company Licensing and Placement permit for Indonesian Migran Worker}

Robert Galavan, John Murray, Costas Markides (2012) states ultimately the challenge of managing the provision of public services is in a way that is positively related to national competitiveness. Interaction among government agencies, regulation and public services, although little affect on national competitiveness, needs great attention. The report on the competitiveness of the state on an annual basis draws attention, a popular perception of this interdependence with pressure on those working in government, public infrastructure, and the provision of public services as an essential component of collective competitiveness. This consideration effectively introduces market forces and consideration to management on the challenges of public services; the influence of public services and the cost of quality of the company's products, which must compete in the global marketplace. Competition in the global market is largely determined by variations in the provision of public services at the national level. in this way, the management of business license planning and licensing regulation for new business premises is an important component of national competitiveness such as providing service, cost, and quality of infrastructure services and legal law, intellectual property, and personal freedom factors.

Azizy (2010) argued that improvements in bureaucratic licensing services conducted by the Regional Government can not be separated from the context of bureaucratic reform. Bureaucratic institutions have a very significant role and function in governance, and can not be replaced by other institutions. Bureaucracy reform is an ongoing effort that every stage of giving change or improvement of bureaucracy to a better direction. Referring to Presidential Regulation no. 81 of 2010 on the Grand Design of Bureaucracy Reform 2010-2025, bureaucratic reform means as a major change in the paradigm and governance of Indonesia.

\section{B. One Stop Integrated service by Local Government}

In accordance with the Regulation of the Minister of Manpower No. 30 of 2015 Concerning One Stop Service, the Ministry of Manpower provides One Stop Service Integrated Service (PTSA) for job placement and expanding opportunity of employment as follows, a) Licensing of domestic worker placement by a private institutions with legal entity; b) Executing license for foreign migrant worker placement by private institutions with legal entity; c) License for the companies that do placement Indonesian migran worker for their own companies; d) Ratification of the plan for the use of foreign worker in Indonesia (RPTKA), f) Permit for Foreign Workers (IMTA); g) Permit to placement / recruit prospective Indonesian migran workers (SIP); h) Recommendations for the establishment of a private agencies for placement Indonesian migrant worker in abroad (representation agency or Private Sector of Placement and Protection of Indonesian Migrant Worker, (PPTKIS)), and i) other services for placement of Indonesian migrant worker and expanding opportunity of employment.

Herson's (2014) Study on Coordination in the Return of Indonesian Migrant Workers in Nunukan District indicates that coordination in the preparation of repatriation planning of migrant workers from the point of debarkation to the origin areas conducted by the local Social Service of Manpower and Transmigration Indonesian Ministry of Manpower and the Province agency of Placement and Protection Service (BP3TKI ) as well as other agencies in the case of coordinated planning through data collection and budget for the return of Indonesian migrant workers to the regions of origin that they has been well implemented. Coordination in the repatriation of Indonesian migrant workers from the debarkation point to the area of origin involved is the local Social Service of Manpower and Transmigration, Indonesian Ministry and Province agency of Placement and Protection Service (BP3TKI) and Unity of Port Security (KP3) port. In general, coordination in the return of Indonesian migrant workers has been done well. However, the problems faced by various agencies in coordination to manage the return of Indonesian migrant workers in Nunukan Regency are the budget and the unsafety repatriation system.

Institutional research conducted by Yudi Rioka Suflan (2014) in his research on Policy Evaluation of Presidential Regulation of the Republic of Indonesia Number 81 Year 2006 on National Agency for Placement and Protection of Indonesian Worker, Tanjungpinang City Study, argued that Presidential Regulation No. 81 of 2006 on The National Agency for Placement and Protection of Indonesian Migrant Worker (BNP2TKI) Tanjungpinang Municipality Year 
2013 (study section 3 on the function of BNP2TKI) has not run well and there are still many things to be considered, as in socialization should be more comprehensive in order to be known by all strata of society functions and BP3TKI. Not only that BP3TKI Tanjungpinang so far only provide socialization to certain locations such as vocational high schools and then in places of shelter, so the existence of BP3TKI can not run effectively. Then in terms of socializations of information also not comprehensive, the lack of coordination between parties or related agencies to make the function of BP3TKI to overlap.

\section{Labor Attaché from the Ministry of Manpower}

In the case of placement and protection programs of Indonesian migran worker conducted by Human Resources in the Representative of the Republic of Indonesia, the subjects referred to are those who perform the diplomatic duties of employment. In the face of migrant workers who work abroad, Robert Galavan, Jhon Murray, and Costas Markides (2008) in addition to suggesting Service Delivery; The challenge here are, above all, the provision of high-quality efficient service; the management of scope and public sector boundaries; and management of linkage to the concept of the 'competing nation'.

Challenges that managers face in each of the following areas:

Wise Counsel; Here we we encounter some very different challenges and dilemmas. No amount of excellent in service delivery wil compensate for poor policy decisions. Poor policy decisions unreleated to substantial service provision may have even more disastrous impact: decisions foreign policy, on international negotiations and agreements, on security, on human rights, on justice and law reform, on educational philosophy deeply affect the fortunes and well-being of a nation. The list is extensive and does not require over-elaboration to make the point. Such decisions are substantially forged at interface between senior politicians holding departemental of sectoral briefs and their senior civil servants. Sometimes they are honed at cabinet table or presidential office, particularly where they have whole-of-government implications, stand at the centre of electoral policy, or are at the eye of political storm.

Robert Galavan, John Murray, Costas Markides (2008) furthermore

Three central challenge for senior public managers are how to acquire and develop the skills that underpin the ability to provide good advice: how to provide advice while cleaving to the professional imperative to speak truth to the power, and how to construct the interface between policy decisions and implementation. Finally, we have the challenge of building the essentially between policy decisions and their implementation. Because the nature of the policy is a consequence of the current status in the placement and protection programs of Indonesian migrant worker where the decision should be seen as anticlimactic - seen in the eyes of some; work for the less talented and perhaps a little unfit or appropriate. In his view, Robert Galavan et al. (2008) pointed,

Stewardship of Values; Underlying public service values are generally agreed on in Western democracies and I will concentrate on these. Their central themes are probity, non partisan Independence, equity in treatment of the citizen, and the fearless provision of independent advice. These commitment have generally been protected by significant security of job tenure and by various unions and staff associations. In turbulent times, clear values that are strongly held are one of the few unchange guidance mechanismes that provide a means of navigationa through poorly understood and rapidly changing circumstances. They remain unambiguous when many other points reference become unclear.

Cultural values that affect organizational performance are also put forward by Robert Gallavan, John Murray and Costas Markides (2008) that as according to Schein. Schein argues that organizational culture has three levels: behavior of the ogranization's members; values to which people attribute their behavior - although stated and operation value may prove different; and assumption and beliefs which grow from value into the realm of the taken for granted where they are scarcely noticed in any conscious manner but nevertheless drive behavior powerpully because the guide the way we do thing here.

David Ahlstrom and Garry D. Bruton, (2010) argue "the impact of culture on organization is broad. For example, culture and affect all aspects of the management of a firm including, but not limited to, strategy, hiring pay/promotion, organization and evaluation of performance".

Fahey dan Randal in the David Ahlstrom dan Garry D. Bruton (2010) explain; culture has an impact not only how communication takes place in 
an organization but also what is actually communicated..

In term of culture context, David Ahsltrom dan Garry D (2010) state,

High-context and low context culture exist. In hign context culture, the context in which what is spoken plays a major role in communication and the behavior of individual. The status of person who is speaking, why the person is speaking, (was it initiated by the speaker or was it in response to a question), and the other person's status all impact the nature of how something is to be communicated. In contrast, in low-context culture, such as the United States, the information is very straightforward, and the context has less impact on how such information is likely to be spoken and interpreted. Nonverbal cues are quite important in high context cultures. In East Asia and other developing regions, such as The Middle East, communication is much higher context and such honorific terms are commonly used. For example, in most East Asian cultures, nonverbal signal, such as silence, or indirect answers, such as "That will be very difficult" (usually a polite way of saying "no" in East Asia form Japan to Indonesia) are critical to understanding what is being communicated.

In the culture is further expressed,So in highcontext culture:

a) Communication is less direct

b) Speech is unhurried and drawn out

c) Greater emphasis is placed on the context or nonverbal cues and less emphasis is placed on the actual information.

d) Interpretation is loser, which sometimes can be problematic for the listener because answers may be indirect and it takes experience on the part of the listener to interpret what was really said

e) face is very important: direct, embarrassing questions or statements are to be avoided, or asked in a very discreet way, sometime via an intermediary.

Subsequently put forward in the lower context, In low context culture:

a) the primary interest in the information and the context is less important

b) the listener wants to get lots of information

c) lack of clarity or ambiguity is generally regarded as negative

d) interpretation should be unequivocal

e) direct and embarrassing questions are often asked; face-saving is not very important.
According Arvind V. Phatak, Rabi S. Bhagat dan Roger J. Kashlak (2009), Culture is a concept that has bee used in several social science disciplines to explain variation in human tought processes in different parts of the world.

In general the culture is seen next Herskovits H. J. In Arvind et al, (2009) as,Culture in the humanmade part of environment. It has both subjective and objective components. Objective culture components are such things as infrastructure of roads, architecture, patterns of music, food, and dress habits. Subjectives culture component include the ways that people categorize exerience, associations, beliefs, attitudes, self-defenitions, role defenitions, norm, and values. Subjective culture help people survive the various demands that are present in an ecological setting since they do not have to reinvent adaptive behaviors but can imitate them or learn from previous generations.

Culture can be seen from several dimensions. This culture is the framework of the average propensity or norms of the main value system that defines culture. The culture is not meant to describe exactly how culture evolves and how it functions or stereotypes certain people in behaving. How to culture or culture of a particular country, although not everyone behaves in the same way.

\section{Supervision from BNP2TKI}

In ensuring the placement and protection programs of Indonesian migran worker, must be run in the right way. In terms of supervision, in relation to supervisory duties, supervisors in placement and protection programs of Indonesian migrant worker must have a high cultural view. Mark P. Salsbury (2013), suggests that in building and preparing societies with complex cultures, where human capital is put into an activity or program, there are at least 3 (three) reasons why development and planning are needed, namely; 1) Large-scale human capital projects require multiple actions and as a result, many hands make lighter work. Simply state, the preparation work needing completion can be done faster with more people, 2) Having capable people who can provide insights, feedback, and help mold the key aspects of a project is a good quality control approach. Increasing per-launch involvement of a limited number of people who can perform the early preparatory work will enhance the quality of the outcome, 3) Every human capital project needs to have champions ready to carry enthusiasm to the project. Waiting until after the announcement and start of a project to enlist and engage champions 
will create a gap in the process, and require senior management to sell more than necessary. While it's senior management's responsibility to communicate and sell the initiative continuously, having additional champions can have a more transmissible effect in generating organizational motivation and commitment.

\section{Research Methodology}

This research is done through observation, interview and documentation with Discrepancy Evaluation Model analysis method in Ministry of Manpower of Republik of Indonesia and The National Agency for Placement and Protection of Indonesian Migrant Worker (BNP2TKI)

The Discrepancy Evaluation Model developed by Malcolm Provus (1969). This model is able to see two important components, namely standard and program performance. According to Malcolm Provus (1969), in using the model Discrepancy Evaluation Model, the following assumptions are used:

The manner in which an evaluation based on Discrepancy Model can be conducted is perhaps more important to practitioners than the assumptions of the model and its theoritical adequacy. As is usually the case, however, a discussion of methodology discloses new theoritical issues to be further considered and resolved. Such a discussion, when based experience, also constitutes the essential test sound theory. Therefore an essential purpose of this chapter is to illuminate the distinctions and procedures needed to activate the model

Some assumption must be posited and further discussion of the evaluation process is necessary if we are to proceed with a clear description of evaluation methodology. The following assumptions are given: (1) it is necessary to evaluate ongoing school programs to make sound decisions about whether to improve, terminate, or maintain them. (2) There is administrative support for program change initiated by program staff rather than by authority superordinate to staff. The initiative action takes the form of setting standards and interpreting discrepancy information. (3) There is administrative support for a distinction between program and evaluation staff personnel and function. Program staff is defined as the persons responsible for planning, organizing, and conducting the work of a project. (4) A nondirective, objective evaluation staff can assist in the definition of standards according to structural criteria, identify and collect performance information relative to standards, and estimate the significance of the observed differences between standard and performance. (5) Problem solving activity required by program staff to improve school program, is dependent on reliable discrepancy information provided by evaluation staff. (6) Problem solving activity will be successful only if program provide by evaluation staff is involved in and committed to the change process. (7) A state of tention can be fostered in program staff that will result in problem-solving activity. (8) Problem-solving success requires pertinent information from evaluation staff and sound decisions from program staff. (9) If an evaluation staff is to have support of the program staff it seeks to evaluate, it must provide visible assistance in a form acceptable to program staff. The only assurance of acceptability is that program purpose be defined by the program staff and the methods of change be determined by them as well.

Table : Evaluation Concepts, Evaluated Aspects and Evaluation Criteria

\begin{tabular}{|l|c|c|}
\hline $\begin{array}{l}\text { Evaluation } \\
\text { Stage }\end{array}$ & \multicolumn{1}{|c|}{ Evaluation Aspecs } & Evaluation Criterias \\
\hline Design & $\begin{array}{c}\text { 1. Placement and protection programs } \\
\text { of Indonesian migrant workers } \\
\text { that it is run by Private sector for } \\
\text { Placement and Protection of } \\
\text { Indonesian Migrant Worker } \\
\text { (PPTKIS) lisenced from the } \\
\text { Ministry of Manpower and } \\
\text { Placement permit by National } \\
\text { Agency of Placement and } \\
\text { Protection of Indonesian Migrant }\end{array}$ & $\begin{array}{l}\text { Manpower and National Agency of Placement and } \\
\text { Protection of Indonesia Migrant Worker (BNP2TKI) } \\
\text { that it is expected that the planning of these programs } \\
\text { and activities further improve the implementation of } \\
\text { placement and protection to Indonesian migrant } \\
\text { worker }\end{array}$ \\
\hline
\end{tabular}




\begin{tabular}{|c|c|c|}
\hline & Worker (BNP2TKI) & \\
\hline & $\begin{array}{l}\text { 2. Placement and protection program } \\
\text { of Indonesian migrant workers } \\
\text { who are submitted to the local } \\
\text { government through a one-stop } \\
\text { integrated service }\end{array}$ & $\begin{array}{l}\text { 2. In accordance with the regulation of Ministry of } \\
\text { Manpower and regulation of the head of National } \\
\text { Agency of Placement and Protection of Indonesian } \\
\text { Migrant Worker (BNP2TKI) on the needs of } \\
\text { programs and activities of placement and protection } \\
\text { of Indonesian migrant workers, various irregularities } \\
\text { that occur in the implementation of placement and } \\
\text { protection of Indonesian labor migrants that it can be } \\
\text { minimized. }\end{array}$ \\
\hline & $\begin{array}{l}\text { 3. Program of placement and } \\
\text { protection of Indonesian migrant } \\
\text { workers conducted by labor } \\
\text { attaches from the Ministry of } \\
\text { Manpower of the Republic of } \\
\text { Indonesia }\end{array}$ & $\begin{array}{l}\text { 3. In accordance with the regulation of Ministry of } \\
\text { Manpower and regulation of the head of National } \\
\text { Agency of Placement and Protection of Indonesian } \\
\text { Migrant Worker (BNP2TKI) on the needs of } \\
\text { programs and activities of placement and protection } \\
\text { of Indonesian migrant workers, various } \\
\text { irregularities that occur in the implementation of } \\
\text { placement and protection of Indonesian labor } \\
\text { migrants that it can be minimized. }\end{array}$ \\
\hline & $\begin{array}{l}\text { 4. Supervision by BNP2TKI for the } \\
\text { placement and protection } \\
\text { programs of Indonesian migrant } \\
\text { worker that they placement by } \\
\text { PPTKIS }\end{array}$ & $\begin{array}{l}\text { 4. In accordance with the regulation of Ministry of } \\
\text { Manpower and regulation of the head of National } \\
\text { Agency of Placement and Protection of Indonesian } \\
\text { Migrant Worker (BNP2TKI) on the needs of } \\
\text { programs and activities of placement and protection } \\
\text { of Indonesian migrant workers, various } \\
\text { irregularities that occur in the implementation of } \\
\text { placement and protection of Indonesian labor } \\
\text { migrants that it can be minimized. }\end{array}$ \\
\hline Installation & $\begin{array}{l}\text { 1. Placement and protection programs } \\
\text { of Indonesian migrant workers } \\
\text { that it is run by Private sector for } \\
\text { Placement and Protection of } \\
\text { Indonesian Migrant Worker } \\
\text { (PPTKIS) lisenced from the } \\
\text { Ministry of Manpower and } \\
\text { Placement permit by National } \\
\text { Agency of Placement and } \\
\text { Protection of Indonesian Migrant } \\
\text { Worker (BNP2TKI) }\end{array}$ & $\begin{array}{l}\text { 1. Guidelines referring to the Employment Placement } \\
\text { and Protection Programs of Indonesian migrant } \\
\text { workers related to the fulfillment of the basic targets } \\
\text { of placement and protection of Indonesian migrant } \\
\text { workers, provide various solutions that need to be } \\
\text { increase performance in the standard of permanent } \\
\text { procedures or advocate the need for new systems in } \\
\text { fulfilling facilities and infrastructure to examine the } \\
\text { required societies. Currently one-stop integrated } \\
\text { service system becomes a trend, whether as needed } \\
\text { or not? }\end{array}$ \\
\hline & $\begin{array}{l}\text { 1. Placement and protection program } \\
\text { of Indonesian migrant workers } \\
\text { who are submitted to the local } \\
\text { government through a one-stop } \\
\text { integrated service }\end{array}$ & $\begin{array}{l}\text { 2. Guidelines referring to the Employment Placement } \\
\text { and Protection Programs of Indonesian migrant } \\
\text { workers related to the fulfillment of the basic targets } \\
\text { of placement and protection of Indonesian migrant } \\
\text { workers, provide various solutions that need to be } \\
\text { increase performance in the standard of permanent } \\
\text { procedures or advocate the need for new systems in } \\
\text { fulfilling facilities and infrastructure to examine the } \\
\text { required societies. Currently one-stop integrated } \\
\text { service system becomes a trend, whether as needed } \\
\text { or not? }\end{array}$ \\
\hline
\end{tabular}




\begin{tabular}{|c|c|c|}
\hline & $\begin{array}{l}\text { 3. Program of placement and } \\
\text { protection of Indonesian migrant } \\
\text { workers conducted by labor } \\
\text { attaches from the Ministry of } \\
\text { Manpower of the Republic of } \\
\text { Indonesia }\end{array}$ & $\begin{array}{l}\text { 3. Guidelines referring to the Employment Placement } \\
\text { and Protection Programs of Indonesian migrant } \\
\text { workers related to the fulfillment of the basic targets } \\
\text { of placement and protection of Indonesian migrant } \\
\text { workers, provide various solutions that need to be } \\
\text { increase performance in the standard of permanent } \\
\text { procedures or advocate the need for new systems in } \\
\text { fulfilling facilities and infrastructure to examine the } \\
\text { required societies. Currently one-stop integrated } \\
\text { service system becomes a trend, whether as needed } \\
\text { or not? }\end{array}$ \\
\hline & $\begin{array}{l}\text { 4. Supervision by BNP2TKI for the } \\
\text { placement and protection } \\
\text { programs of Indonesian migrant } \\
\text { worker that they placement by } \\
\text { PPTKIS }\end{array}$ & $\begin{array}{l}\text { 4. Guidelines referring to the Employment Placement } \\
\text { and Protection Programs of Indonesian migrant } \\
\text { workers related to the fulfillment of the basic targets } \\
\text { of placement and protection of Indonesian migrant } \\
\text { workers, provide various solutions that need to be } \\
\text { increase performance in the standard of permanent } \\
\text { procedures or advocate the need for new systems in } \\
\text { fulfilling facilities and infrastructure to examine the } \\
\text { required societies. Currently one-stop integrated } \\
\text { service system becomes a trend, whether as needed } \\
\text { or not? }\end{array}$ \\
\hline Process & $\begin{array}{l}\text { 1. Placement and protection programs } \\
\text { of Indonesian migrant workers } \\
\text { that it is run by Private sector for } \\
\text { Placement and Protection of } \\
\text { Indonesian Migrant Worker } \\
\text { (PPTKIS) lisenced from the } \\
\text { Ministry of Manpower and } \\
\text { Placement permit by National } \\
\text { Agency of Placement and } \\
\text { Protection of Indonesian Migrant } \\
\text { Worker (BNP2TKI) }\end{array}$ & $\begin{array}{l}\text { 1. Implementation of service function for the } \\
\text { placement and protection programs of Indonesian } \\
\text { migrant workers, coordination function and human } \\
\text { resource development function that can produce } \\
\text { more efficient and effective output or higher yield. }\end{array}$ \\
\hline & $\begin{array}{l}\text { 2. Placement and protection program } \\
\text { of Indonesian migrant workers } \\
\text { who are submitted to the local } \\
\text { government through a one-stop } \\
\text { integrated service }\end{array}$ & $\begin{array}{l}\text { 2. Implementation of service function for the } \\
\text { placement and protection programs of Indonesian } \\
\text { migrant workers, coordination function and human } \\
\text { resource development function that can produce } \\
\text { more efficient and effective output or higher yield. }\end{array}$ \\
\hline & $\begin{array}{l}\text { 3. Program of placement and } \\
\text { protection of Indonesian migrant } \\
\text { workers conducted by labor } \\
\text { attaches from the Ministry of } \\
\text { Manpower of the Republic of } \\
\text { Indonesia }\end{array}$ & $\begin{array}{l}\text { 3. Implementation of service function for the } \\
\text { placement and protection programs of Indonesian } \\
\text { migrant workers, coordination function and human } \\
\text { resource development function that can produce } \\
\text { more efficient and effective output or higher yield.. }\end{array}$ \\
\hline & $\begin{array}{l}\text { 4. Supervision by BNP2TKI for the } \\
\text { placement and protection } \\
\text { programs of Indonesian migrant } \\
\text { worker that they placement by } \\
\text { PPTKIS }\end{array}$ & $\begin{array}{l}\text { 4. Implementation of service function for the placement } \\
\text { and protection programs of Indonesian migrant } \\
\text { workers, coordination function and human resource } \\
\text { development function that can produce more } \\
\text { efficient and effective output or higher yield.. }\end{array}$ \\
\hline
\end{tabular}




\begin{tabular}{|c|c|c|}
\hline \multirow[t]{4}{*}{$\begin{array}{l}\text { Implementati } \\
\text { on }\end{array}$} & $\begin{array}{l}\text { 1. Placement and protection programs } \\
\text { of Indonesian migrant workers } \\
\text { that it is run by Private sector for } \\
\text { Placement and Protection of } \\
\text { Indonesian Migrant Worker } \\
\text { (PPTKIS) lisenced from the } \\
\text { Ministry of Manpower and } \\
\text { Placement permit by National } \\
\text { Agency of Placement and } \\
\text { Protection of Indonesian Migrant } \\
\text { Worker (BNP2TKI) }\end{array}$ & $\begin{array}{l}\text { 1. Seeing the achievement of the Indonesian migrant } \\
\text { workers achievement goals in the placement and } \\
\text { protection programs of Indonesian migrant workers } \\
\text { during pre-placement, placement and post- } \\
\text { placement and to improve the timeliness of the } \\
\text { services provided in the new system. }\end{array}$ \\
\hline & $\begin{array}{l}\text { 2. Placement and protection } \\
\text { program of Indonesian migrant } \\
\text { workers who are submitted to } \\
\text { the local government through a } \\
\text { one-stop integrated service }\end{array}$ & $\begin{array}{l}\text { 2. Seeing the achievement of the Indonesian migrant } \\
\text { workers achievement goals in the placement and } \\
\text { protection programs of Indonesian migrant workers } \\
\text { during pre-placement, placement and post-placement } \\
\text { and to improve the timeliness of the services } \\
\text { provided in the new system.. }\end{array}$ \\
\hline & $\begin{array}{l}\text { 3. Program of placement and } \\
\text { protection of Indonesian migrant } \\
\text { workers conducted by labor } \\
\text { attaches from the Ministry of } \\
\text { Manpower of the Republic of } \\
\text { Indonesia }\end{array}$ & $\begin{array}{l}\text { 3. Seeing the achievement of the Indonesian migrant } \\
\text { workers achievement goals in the placement and } \\
\text { protection programs of Indonesian migrant workers } \\
\text { during pre-placement, placement and post-placement } \\
\text { and to improve the timeliness of the services } \\
\text { provided in the new system. }\end{array}$ \\
\hline & $\begin{array}{l}4 \text { Supervision by BNP2TKI for the } \\
\text { placement and protection } \\
\text { programs of Indonesian migrant } \\
\text { worker that they placement by } \\
\text { PPTKIS }\end{array}$ & $\begin{array}{l}\text { 4. Seeing the achievement of the Indonesian migrant } \\
\text { workers achievement goals in the placement and } \\
\text { protection programs of Indonesian migrant workers } \\
\text { during pre-placement, placement and post-placement } \\
\text { and to improve the timeliness of the services } \\
\text { provided in the new system. }\end{array}$ \\
\hline
\end{tabular}

\section{Result}

References to the results of the above assessment compared to the achievement in accordance with the provisions related to legal documents mandated by the law is done $100 \%$, the performance evaluation of the Ministry of Manpower at $80.35 \%$, BNP2TKI at $78 \%$ rating, Consumer Satisfaction Index Survey at $79 \%$, and subjectivity of interviews at $80 \%$, that is:

Based on the target weight of $50 \%$ achieved the weight of $39.19 \%$ shows all the internal aspects of government organizations that conduct various programs and activities in realizing the results of placement and protection for Indonesian migrant

workers and human resources apparatus, and realize the implementation of the placement and protection of Indonesian migrant workers can be maximized by $83.99 \%$ or there is a gap of $16.01 \%$.

\section{Discussion}

\section{Company Licensing and Placement Permit for Indonesian Migran Worker}

The result of the evaluation of $25 \%$ weight over the placement and protection programs of Indonesian migran worker which licensing of PPTKIS to organize the Indonesian migrant 
workers placement service provided by the Ministry of Manpower and a permit of placement by the BNP2TKI is $21.34 \%$ which shows that the maximum achievement and the effectiveness of the program is only reached $21.34 \%$ from the $25 \%$ target indicating that the authority over the dualism of leadership of the placement and protection of Indonesian migrant workers that should be owned by the Ministry of Manpower has not been optimal.

\section{One Stop Integrated service by Local Government}

From the target of $25 \%$ the placement and protection programs of Indonesian migrant worker submitted to the district / municipal government through one-stop integrated service is only reached $21.18 \%$ from the $25 \%$ target which is an activity to strengthen the role of the state through One Stop Service Integrated Institution (LTSA) in regency / city. These LTSAs can provide services that are popularized in the placement and protection of workers to be met.

\section{Labor Attaché from the Ministry of Manpower}

From the target of the placement and protection programs of Indonesian migrant worker servised by labor attaches from the Ministry of Manpower showed an increase of $21.18 \%$ from the $25 \%$ target indicating that the need to resolve the migrant worker issues in accordance with labor law applicable in the international labor convention there is still a gap of $3,82 \%$.

\section{Supervision from BNP2TKI}

From the target of the oversight program for the placement of Indonesian migrant workers in abroad by BNP2TKI supervision only reached with the weight of $21.50 \%$ from the $25 \%$ target indicating that the supervision whose results are submitted in the form of recommendation of follow-up action to the Ministry of Manpower with the necessity to run whit it.

Overall Outcome (50\% weight) resulting from the implementation of the placement and protection programs of Indonesian migrant worker, which perceived not only in the internal Ministry of Manpower and BNP2TKI. Output or outcome generated is the achievement in the placement and protection programs of Indonesian migrant worker that it run by the human resources of the Ministry of Manpower and BNP2TKI. Achievement rate $42.60 \%$ from the target $50 \%$ or there is a gap of $7.40 \%$.
Based on the Discrepancy Evaluation Model results on the design, installation, process and implementation of this program focuses on leadership dualism in granting licenses to the placement and protection programs of Indonesian migran worker between the Ministry of Manpower and the Agency for the Placement and Protection of Indonesian Migrant Worker, the transfer of authority and duty of assistance to the government district / city through a one-stop integrated service, authority to establish labor attaches in country representatives in overseas from the Ministry of Manpower of the Republic of Indonesia, and supervision of the placement of Indonesian migrant workers Company abroad by BNP2TKI. The criteria used to measure the standards and performance of this program.

Based on the objectives, the criteria and targets contained in the design, installation, process and implementation of the evaluation program of the placement and protection program of Indonesian migrant worker between the Ministry of Manpower and BNP2TKI have been carried out with a "medium" value in accordance with predetermined targets and an average score of $83.99(0-100)$.

\section{Conclusions}

The design of the current overseas placement and protection program of Indonesian migrant worker has accommodated the role of local governments in the placement and protection services who have not been accommodated through the One Stop Integrated Services (LTSA) before. This reinforcement implies the delegation of authority owned by the Ministry of Manpower and BNP2TKI to the local goverment to establish One Stop Integrated Services (LTSA).

The placement and protection of Indonesian migrant workers who have been run by Private Sector of Placement and Protection of Indonesian Migrant Worker (PPTKIS) is a mandate from Law Number 39 Year 2004 on the Placement and Protection of Indonesian Migrant Worker. However, in practice there are irregularities to the provisions of the law, such as documents not in accordance with actual data, placements not in accordance with procedures and placement of female workers working in the domestic sector to countries that do not have protection in the domestic sector.

Based on the evaluation of this program has shown that the program of placement and 
protection of Indonesian migran workers has been running well although there are still problems that need to be resolved further. In design, installation, process and implementation of placement and protection program of Indonesian migrant workers indicates that the overall effort has not run optimally.

\section{Recommendations}

1. The institutional relationship between the Ministry of Manpower and BNP2TKI needs to be reformulate in accordance with the provisions of the laws and regulations so that the Ministry of Manpower and BNP2TKI perform their main duties and functions in accordance with the laws and regulations that form them. The overlapping authority in taking the policy should be returned to the President for proper evaluation.

2. Provisions of Law Number 39 Year 2004, Article 10 states the Implementation of overseas migrant placement consisting of: a. Government; b. Private placement of overseas migrant worker. In accordance with the provisions of the overseas migrant worker placement by the private sector, it has encouraged the practice of Private Sector of Placement and Protection of Indonesian Migrant Worker (PPTKIS) to comply with the provisions of Law Number 39 Year 2004 Article 51. Therefore, related provisions passed improvement through the discussion of the Indonesian Workers Protection Bill overseas which is currently being discussed in the parliament of Indonesia.

3. The need to encourage the establishment and strengthening of One Stop Integrated Service in each region as regulated in Law Number 23 Year 2014 on Regional Government so that the implementation of placement and protection of overseas workers can be optimized. This is related to the widespread placement by the private sector in an illegal way, which is done by placing overseas migrant worker, for example young woman from villages in Indramayu, West Java. By PPTKIS placed in a house untouched by legal protection, culture in Saudi Arabia, can not touch Arabs. In Saudi Arabian society culture, due to different cultural factors, to marry only, for a Saudi citizen, needs to reach the establishment, so many of them do not marry until old age. At the same time when PPTKIS places the woman overseas migrant worker into their homes, the woman is considered slave and treated like a property right.
4. To provide legal certainty, in order to protect Indonesian migrant workers and / or migrant workers as a whole, it is necessary to amend Law No. 39 of 2004 on the Placement and Protection of Overseas Workers.

\section{Referrence}

[1] Anderson, Dean, Andersan, Ackerman, Linda., Beyond Change Management: How to Achive Breakthrought Concious Change Leadership, (Pfeifer, San Fransisco, CA, 2010)

[2] Azizy., at all, Change Management dalam Reformasi Birokrasi, Gramedia Pustaka Utama, Jakarta, 2007

[3] Azizy., at all, Change Management dalam Reformasi Birokrasi, Gramedia Pustaka Utama, (Jakarta, 2007)

[4] BNP2TKI., Standar Operasional Prosedur Pelayanan Penempatan Tenaga Kerja Indonesia, (Jakarta 2012)

[5] BNP2TKI, Pusat Data Penelitian Pengembangan dan Informasi BNP2TKI, (Jakarta, 2016)

[6] Catherine, Truss., David Mankin, Clare Kelliner., Strategic Human Resource Management, Oxford University Press, New York, 2012

[7] Christopher A.Barlett, Paul W. Beamish., Transnational Managment, sixth edition, The McGrow-Hill Companies Inc., 1221 Avenue of the Americas, New York, 2011.

[8] Creating a Culture of Heathy Living, Building Our Understanding: Key Concepts of Evaluation What is it and how do you do it? http://www.cdc.gov/nccdphp/dch/programs/he althycommunitiesprogram/tools/pdf/eval_plan ning.pdf (diakses pada 13 April 2016)

[9] Dave, Ulrich, at. all., HR Transformation, Building Human Resources from the Outside In, (Mc Graw Hill, 2009)

[10]David Ahlstrom, Garry D. Brutton, International Management, Strategy and Culture in the Emerging World, South Western Cengage Learning 5191 Natop Boulevard Mason, OH 45040 USA, 2010

[11]Demartoto, Argyo at all., Analisis Kebutuhan Gender, Kajian mengenai Pembekalan Tenaga Kerja Wanita yang akan di Kirim ke Luar Negeri dalam Rangka Penyusunan Kebijakan Responsif Gender di Kabupaten Karanganyar, (Depdiknas, 2007) 
[12]Dunamis, Knowledge Management, Succesful Implementation of $\mathrm{KM}$ in Indonesia, PT. Dunamis Intra Sarana, Jakarta, 2013

[13]Esther Cameron, Mike Green., Making Sence of Change Management., 120 Pentonville Road London N19JN United Kingdom, 2009

[14]Ellen R. Auster, Krista K.Wylie and Michael S. Valente., Strategic Organizational Change, Building Change Capabilllities in Your Organization., Palgrave Macmillan, Houndmills, Basingstoke, Hampshire RG21 6XS and 175 Fifth Avenue, New York, 2005

[15]Europa Standard, http://ec.europa.eu/smartregulation/evaluation/docs/standards_c_2002 5267_final_en.pdf (diakses pada 13 April 2016)

[16]Fransesco Longo, Daniela Christofoli., Strategic Change Management in the Public Sector., John Wiley \& Sons Ltd, The Atrium, Southern Gate, Chichester West Sussex PO19 8SQ England, 2007

[17]Fred Luthans, Jonathan P.Doh., International Management, Culture, Strategy, and Behavior, Eight Edition, The McGraw Hill Companies, Inc., 1221 Avenue of the America, New York, 2012

[18]Galavan, Robert, Murray, John, Markides , Costas., Strategy, Innovation and Change Challenge for Management, (Oxford University Press Inc., New York, 2008)

[19]Geoffrey Brewer, Barb Sanford., Decade of Change, Managing in times of uncertanty., Gallup Press 1251 Avenue of the America New York, 2011

[20]Hall W, Bradlay., The New Human Capital Strategy, Improving the value of the most important Investment - year ater year, (Amacom, American Management Association, USA, 2008)

[21]Helen Deresky., International Management Managing Across Borders and Cultures, Text and Cases, Seven Edition., Pearson Education, Inc., Publishin as Prentice Hall, One Lake Street, Upper Saddle River, New Jersey 07458, 2011

[22]Hermawan, Eko., Evaluasi Reformasi Birokrasi pada Sektor Pelayanan di Kabupaten Kudus (tesis). Semarang (Universitas Diponegoro, 2011)

[23]Hilmy, Umu., Urgensi Perubahan UU Nomor: 39 Tahun 2004 tentang Penempatan dan Perlindungan Pekerja Indonesia di Luar Negeri, RDP antara Pakar dengan Panja
Pekerja Indonesia (Komisi IX tanggal 16 Desember 2010)

[24] http://repository.unhas.ac.id/bitstream/handle/ 123456789/1598/BAB\%20II.pdf (diakses tanggal 17 April 2016)

[25]Indraswati, Yulia., Analisis Strategi Reformasi Birokrasi di Departemen Keuangan Republik Indonesia (Skripsi). Jakarta (Universitas Indonesia, 2008)

[26]Ingham, Jon., Strategic Human Capital Management, (Jordan Hill, Oxford Burlington, USA, 2007)

[27]Iriyani, Omega., Public Service Quality Analysis Investment In Office And OneStopshop City Metro Gate Post Survey Index Integrity National Public Servicein 2011 by The Anti Corruption Commission, (Study of Licensing Services and Building Permit Trading License), Jurnal Kebijakan dan Pembangunan Vol. 1 No. 2 (2014)

[28]John M, Bryson., Strategic Planning for Public and Nonprofit Organization, 3rd edition, John Wiley \& Sons, Inc, 2004

[29]Khan, Inayat., Spiritual Dimensionof Psycology, (Omega Publication, New York, 1981)

[30]Khozin, Muhammad.. Evaluasi Implementasi Kebijakan Standar Pelayanan MinimalBidang Kesehatan di Kabupaten Gunungkidul. (Jurnal Studi Pemerintahan, Volume 1, Nomor 1 Agustus 2010)

[31]Komisi IX DPR RI., Naskah Akademik RUU Perlindungan Pekerja Indonesia di Luar Negeri, (Jakarta, 2012)

[32]Kusumandani, Wahyu Dwi., Pengaruh Kualitas Pelayanan Terhadap Lembaga, studi pada Tenaga Kerja Indonesia di Perusahaan Pengerah Tenaga Kerja Indonesia di Depok terhadap Badan Nasional Penempatan dan Perlindungan TKI, (Skripsi, FISIP UI, 2012)

[33]Malcolm, Provous., The Discrevans Evaluation Model, An Approach to Local Program Inprovement and Development, (Pittburgh Public Schools, Washinton DC, 1969)

[34]Mark, P. Salsbury., Human Capital Management, Leveraging Your Workforce for a Competitive Advantage, (New York, 2013)

[35]Michael E. Porter., Competitive Strategy, Techniques for Analyzing Industries and Competitors., The Three Press, A Division of Simon \& Schuster Inc. 1230 Avenue of the Americas New York, 1980 
[36]__ Porter, On Strategy, Harvard Business

Review Press, Boston, Massachusetts, 2011

[37]Naskah tentang TKI yang disusun oleh Ecosoc Rights dkk., Jakarta, 2010.

[38]Nasution, S., Metode Penelitian Naturalistik Kualitatif (Bandung: Tarsito, 2003)

[39]Nurbani , Mirna., Reformasi Birokrasi Pemerintah Kota Surakarta (Tesis). Semarang, (Universitas Diponegoro, 2009)

[40]Palebangan, Herson., Koordinasi Dalam Pemulangan Tenaga Kerja Indonesia Di Kabupaten Nunukan., eJournal Ilmu Pemerintahan, 2 (3) 2014).

[41]Pantzalis, Crhistos, at. all., Equity Market Valuation of Human Capital and Stock Returns, Journal of Banking and Finance 33, 2009

[42]Peraturan Menteri Ketenagakerjaan Nomor 30 Tahun 2015 Tentang Layanan Satu Atap

[43]Phatak, Arvind. Arvind., Bhagat, S. Rabi \& Kashlak, J. Roger., International Management, Managing in a Divers and Dynamic Global Environment, second edition, (McGraw Hill, USA, 2009)

[44]Qadir, A. Jailani., http://abjaykutai.blogspot. com/2009/10/tugas-pembangunan-kelembaga an.html, di download tanggal 4 April 2016

[45]R. Wayne Monde, Robert M. Noe, Human Resource Managament, Fifth Edition, A Division of Simon \& Schuster Inc. 160 Gould Street, Needham Heights, Massachusetts 02194, 1993

[46]Ray French., Cross Cultural Management in work organization, (CIPD House, London, second ed, 2010)

[47]Reros, A. William., Analisis Keberhasilan Implementasi Kebijakan Pelayanan Publik pada Perusahaan Daerah Air Minum Manado. Jurnal Ekonomi dan Manajemen Volume 8, Nomor 1, Februari 2007

[48]Sadu, Wasistiono, dkk., Perkembangan organisasi kecamatan dari masa ke masa. Bandung: Fokusmedia, 2009

[49]Steel, M. Sara, http://www.joe.org/joe/1970summer/1970-2a1.pdf (diakses pada 13 April 2016)

[50]Suflan Yudi Rioka, Evaluasi Kebijakan Peraturan Presiden Nomor 81 Tahun 2006 Tentang Badan Nasional Penempatan Dan Perlindungan Tenaga Kerja Indonesia, Studi Kota Tanjungpinang, (Universitas Maritim Raja Haji Tanjungpinang 2014)
[51]Sugiyono, Memahami Penelitian Kualitatif (Bandung: CV.Alfabeta, 2010)

[52]Thomas L. Wheelen, J. David Hunger, Alan N. Hoffman, Charles E. Bamford., Concept in Strategic Management and Business Policy, Globalization, Innovation and Sustainability, Fourteenth Edition, Pearson Education, Inc., One Lake Street, Upper Saddle River, New Jersey, 07458, 2015

[53]Twersky, Fay, Karen, Lindblom., Evalution Principles and Practices, An Internal Working Paper,

http://www.hewlett.org/uploads/documents/Ev aluationPrinciples-FINAL.pdf, di akses pada 13 April 2016)

[54]__, Brocbank, Wayne, at all., Global HR Competencies, Mastering Competitive Value from the outside In, McGraw-Hill, 2013

[55]United States General Accounting Office., Performance Measurement and Evaluation Definitions And Relationships, http://www. gao.gov/special.pubs/gg98026.pdf (diakses pada 13 April 2016)

[56]Undang-undang No.37 tahun 1999 tentang Hubungan Luar Negeri, Pemerintah Republik Indonesia

[57]Web Center for Social Research, http://www. socialresearchmethods.net/kb/interval.html (diakses pada 13 April 2016)

[58]Wilkins, David., at all, Leadership Pure and Simple, How Transformative Leader Create Winning Organization, (McGraw Hill, New York, 2013)

[59]Zuhal, Konwledge \& Innovation, Flatporm Kekuatan Daya Saing, PT. Gramedia Pustaka Utama Jakarta, 2010 